\title{
Wautersia gen. nov., a novel genus accommodating the phylogenetic lineage including Ralstonia eutropha and related species, and proposal of Ralstonia [Pseudomonas] syzygii (Roberts et al. 1990) comb. nov.
}

Correspondence Mario Vaneechoutte mario.vaneechoutte@ugent.be

\author{
Mario Vaneechoutte, ${ }^{1}$ Peter Kämpfer, ${ }^{2}$ Thierry De Baere, ${ }^{1}$ Enevold Falsen ${ }^{3}$ \\ and Gerda Verschraegen ${ }^{1}$
}

Comparative 16S rDNA sequence analysis indicates that two distinct sublineages, with a sequence dissimilarity of $>4 \%$ (bootstrap value, $100 \%$ ), exist within the genus Ra/stonia: the Ralstonia eutropha lineage, which comprises Ralstonia basilensis, Ralstonia campinensis, R. eutropha, Ralstonia gilardii, Ralstonia metallidurans, Ralstonia oxalatica, Ralstonia paucula, Ralstonia respiraculi and Ralstonia taiwanensis; and the Ralstonia pickettii lineage, which comprises Ralstonia insidiosa, Ralstonia mannitolilytica, R. pickettii, Ralstonia solanacearum and Ralstonia syzygii comb. nov. (previously Pseudomonas syzygii). This phylogenetic discrimination is supported by phenotypic differences. Members of the $R$. eutropha lineage have peritrichous flagella, do not produce acids from glucose and are susceptible to colistin, in contrast to members of the $R$. pickettii lineage, which have one or more polar flagella, produce acid from several carbohydrates and are colistin-resistant. Members of the $R$. pickettii lineage are viable for up to 6 days on tryptic soy agar at $25^{\circ} \mathrm{C}$, whereas members of the $R$. eutropha lineage are viable for longer than 9 days. It is proposed that species of the $R$. eutropha lineage should be classified in a novel genus, Wautersia gen. nov. Finally, based on the literature and new DNA-DNA hybridization data, it is proposed that Pseudomonas syzygii should be renamed Ralstonia syzygii comb. nov.

\section{INTRODUCTION}

The genus Ralstonia (Yabuuchi et al., 1995) was created to accommodate bacteria from ecologically diverse niches that were classified previously as Burkholderia (Yabuuchi et al., 1992) and Alcaligenes. The type species of the genus - Ralstonia pickettii (type strain, ATCC $27511^{\mathrm{T}}$ ) was regarded originally as the only representative of clinical importance (Fass \& Barnishan, 1976; Fujita et al., 1981;

Published online ahead of print on 1 August 2003 as DOI 10.1099/ ijs.0.02754-0.

The GenBank/EMBL/DDBJ accession numbers for the 16S rRNA gene sequences of Ralstonia insidiosa strains CCUG 46389 and CCUG 46388 are AJ507103 and AJ539233.

The results of lactose and maltose acidification by Ralstonia pickettii strains, the 16S rRNA gene signature sequences of the Ralstonia species, detailed phenotypic data of different species and a similarity matrix of the 16S rDNA sequences are available as supplementary material (Tables A1, A2, A3 and A4, respectively) in IJSEM Online.
Kahan et al., 1983; Gardner \& Shulman, 1984; Verschraegen et al., 1985; Roberts et al., 1990a; Lacey \& Want, 1991; Dimech et al., 1993; Raveh et al., 1993). Recently, several novel species [Ralstonia basilensis (Steinle et al., 1998; Goris et al., 2001), Ralstonia campinensis (Goris et al., 2001), Ralstonia gilardii (Coenye et al., 1999), Ralstonia insidiosa (Coenye et al., 2003a), Ralstonia metallidurans (Goris et al., 2001), Ralstonia mannitolilytica corrig. (De Baere et al., 2001; original spelling, Ralstonia mannitolytica), Ralstonia oxalatica (Sahin et al., 2000), Ralstonia paucula (Osterhout et al., 1998; Vandamme et al., 1999; Moissenet et al., 1999), Ralstonia respiraculi (Coenye et al., 2003b) and Ralstonia taiwanensis (Chen et al., 2001)] have been described, some of which are of moderate clinical importance.

In a previous study (De Baere et al., 2001), it was indicated that species of the genus Ralstonia can be separated clearly into two phenotypically and genotypically distinct groups. Here, it is proposed to consolidate these findings by allocating one group of species to a novel genus, Wautersia 
Table 1. List of Ralstonia and Wautersia species and strains tested during this and previous studies

\begin{tabular}{|c|c|c|c|}
\hline Species & Type strain & Strains tested in this study & Reference \\
\hline Ralstonia insidiosa (Coenye et al. 2003) biovar 1 & LMG $21421^{\mathrm{T}}=$ CCUG $46789^{\mathrm{T}}$ & $\begin{array}{l}\text { LMG } 21421^{\mathrm{T}} \text {, CCUG 38965, CCUG 46212, CCUG } \\
\text { 46213, CCUG 47187, CCUG } 47416\end{array}$ & $\begin{array}{l}\text { Coenye et al. (2003a); } \\
\text { this study }\end{array}$ \\
\hline Ralstonia insidiosa (Coenye et al. 2003) biovar 2 & & $\begin{array}{l}\text { CCUG 46387, CCUG 46388, CCUG 46389, CCUG } \\
47426\end{array}$ & $\begin{array}{l}\text { Coenye et al. (2003a); } \\
\text { this study }\end{array}$ \\
\hline Ralstonia mannitolilytica (De Baere et al. 2001) & $\begin{array}{l}\text { CCUG } 38408^{\mathrm{T}}=\text { CCUG } 45027^{\mathrm{T}}=\mathrm{LMG} 6866^{\mathrm{T}} \\
=\mathrm{NCIMB} 10805^{\mathrm{T}}\end{array}$ & LMG 6866T , LMG 19090, LMG 19091, LMG 19092 & De Baere et al. (2001) \\
\hline $\begin{array}{l}\text { Ralstonia pickettii (Ralston et al. 1973) Yabuuchi } \\
\text { et al. } 1996 \text { comb. nov.* }\end{array}$ & $\begin{array}{l}\text { ATCC } 27511^{\mathrm{T}}=\text { CCUG } 3318^{\mathrm{T}}=\text { DSM } 6297^{\mathrm{T}} \\
=\text { LMG } 5942^{\mathrm{T}}=\text { NCTC } 11149^{\mathrm{T}}\end{array}$ & $\begin{array}{l}\text { ATCC } 27511^{\mathrm{T}} \text {, ATCC } 27512, \text { LMG 7014, LMG } 7015 \text {, } \\
\text { LMG 7160, LMG 19083, LMG 19084, LMG 19085, } \\
\text { LMG 19086, LMG } 19088\end{array}$ & Yabuuchi et al. (1996) \\
\hline $\begin{array}{l}\text { Ralstonia solanacearum (Smith 1896) Yabuuchi } \\
\text { et al. } 1996 \text { comb. nov. }\end{array}$ & $\begin{array}{l}\text { A. Kelman } 60-1^{\mathrm{T}}=\text { ATCC } 11696^{\mathrm{T}}=\text { CCUG } 14272^{\mathrm{T}} \\
=\text { DSM } 9544^{\mathrm{T}}=\text { LMG } 2299^{\mathrm{T}}\end{array}$ & LMG $2299^{\mathrm{T}}, \mathrm{LMG} 2303$ & Yabuuchi et al. (1996) \\
\hline $\begin{array}{l}\text { Ralstonia [Pseudomonas] syzygii (Roberts et al. } \\
\text { 1990) comb. nov. }\end{array}$ & $\mathrm{R} 001^{\mathrm{T}}=$ ATCC $49543^{\mathrm{T}}=\mathrm{LMG} 10661^{\mathrm{T}}$ & LMG 6969 & This study \\
\hline $\begin{array}{l}\text { Wautersia [Ralstonia] basilensis (Steinle et al. } \\
\text { 1999) comb. nov. }\end{array}$ & $\mathrm{RK}^{\mathrm{T}}=\mathrm{DSM} 11853^{\mathrm{T}}=\mathrm{LMG} 18990^{\mathrm{T}}=\mathrm{LMG} 19474^{\mathrm{T}}$ & LMG $18990^{\mathrm{T}}$ & Steinle et al. (1999) \\
\hline $\begin{array}{l}\text { Wautersia [Ralstonia] campinensis (Goris et al. } \\
\text { 2001) comb. nov. }\end{array}$ & $\mathrm{WS}^{\mathrm{T}}=\mathrm{CCUG} 44526^{\mathrm{T}}=\mathrm{LMG} 19282^{\mathrm{T}}$ & & Goris et al. (2001) \\
\hline $\begin{array}{l}\text { Wautersia [Ralstonia] eutropha (Davis 1969) } \\
\text { Yabuuchi et al. } 1996 \text { comb. nov. }\end{array}$ & $\begin{array}{l}\text { ATCC } 17697^{\mathrm{T}}=\text { CCUG } 1776^{\mathrm{T}}=\text { DSM } 531^{\mathrm{T}} \\
=\text { LMG } 1199^{\mathrm{T}}\end{array}$ & LMG 1199 ${ }^{\mathrm{T}}$, LMG 1194, LMG 1201 & Yabuuchi et al. (1996) \\
\hline $\begin{array}{l}\text { Wautersia [Ralstonia] gilardii (Coenye et al. 1999) } \\
\text { comb. nov. }\end{array}$ & $\begin{array}{l}\text { Gilardi } 4325^{\mathrm{T}}=\text { ATCC } 700815^{\mathrm{T}}=\text { CCUG } 38401^{\mathrm{T}} \\
=\mathrm{LMG} 5886^{\mathrm{T}}\end{array}$ & $\begin{array}{l}\text { LMG } 5886^{\mathrm{T}} \text {, LMG 3400, LMG 15537, NF 926, } \\
\text { NF } 933\end{array}$ & Coenye et al. (1999) \\
\hline $\begin{array}{l}\text { Wautersia [Ralstonia] metallidurans (Goris et al. } \\
\text { 2001) comb. nov. }\end{array}$ & $\mathrm{CH} 34^{\mathrm{T}}=\mathrm{CIP} 107179^{\mathrm{T}}=\mathrm{DSM} 2839^{\mathrm{T}}=\mathrm{LMG} 1195^{\mathrm{T}}$ & & Goris et al. (2001) \\
\hline $\begin{array}{l}\text { Wautersia [Ralstonia] oxalatica (ex Khambata and } \\
\text { Bhat 1953) Sahin et al. } 2000 \text { comb. nov. }\end{array}$ & $\begin{array}{l}\mathrm{Ox} 1^{\mathrm{T}}=\text { ATCC } 11883^{\mathrm{T}}=\text { CCUG } 2086^{\mathrm{T}}=\text { DSM } 1105^{\mathrm{T}} \\
=\mathrm{LMG} 2235^{\mathrm{T}}\end{array}$ & & Sahin et al. (2000) \\
\hline $\begin{array}{l}\text { Wautersia [Ralstonia] paucula (Vandamme et al. } \\
\text { 1999) comb. nov. }\end{array}$ & ATCC $700817^{\mathrm{T}}=$ CCUG $12507^{\mathrm{T}}=\mathrm{LMG} 3244^{\mathrm{T}}$ & LMG $3244^{\mathrm{T}}$, LMG 3515 & Vandamme et al. (1999) \\
\hline $\begin{array}{l}\text { Wautersia [Ralstonia] respiraculi (Coenye et al. } \\
\text { 2003) comb. nov. }\end{array}$ & $\operatorname{AU} 3313^{\mathrm{T}}=\mathrm{LMG} 21510^{\mathrm{T}}=\mathrm{CCUG} 46809^{\mathrm{T}}$ & & Coenye et al. (2003b) \\
\hline $\begin{array}{l}\text { Wautersia [Ralstonia] taiwanensis (Chen et al. } \\
\text { 2001) comb. nov. }\end{array}$ & $\mathrm{R} 1^{\mathrm{T}}=\mathrm{CCUG} 44338^{\mathrm{T}}=\mathrm{LMG} 19424^{\mathrm{T}}$ & & Chen et al. (2001) \\
\hline
\end{tabular}

${ }^{\star}$ Two DNA groups are present (De Baere et al., 2001; this study). 


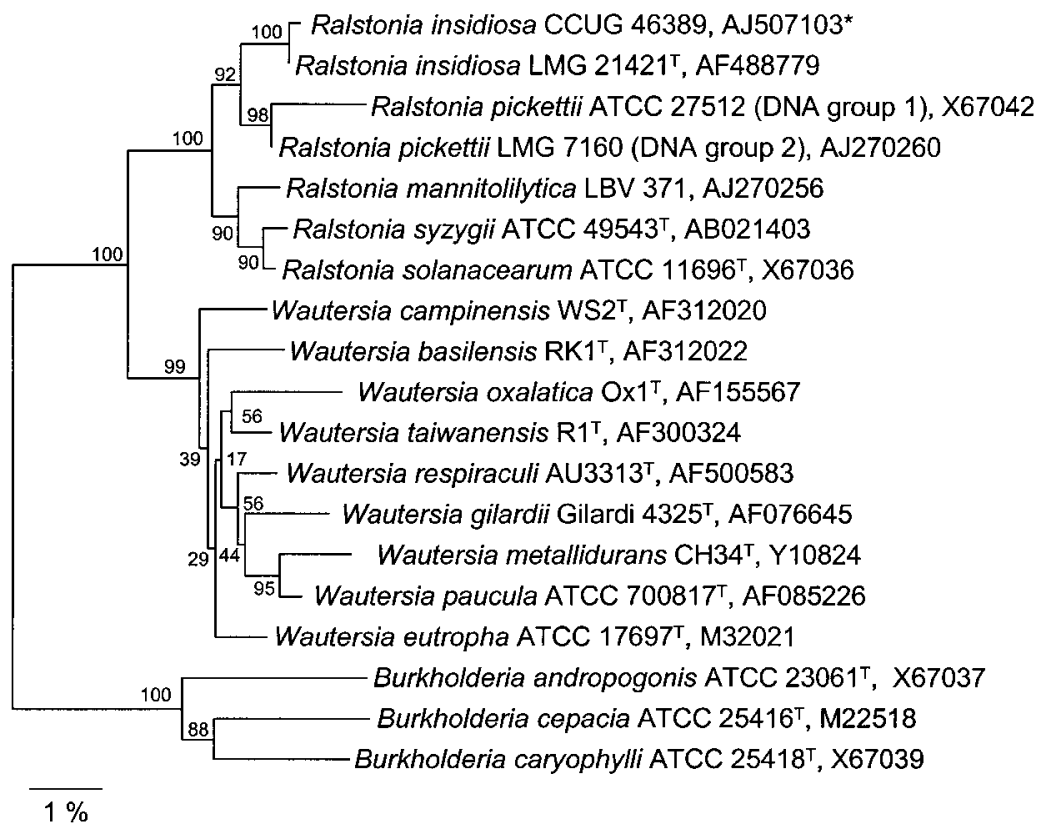

Fig. 1. Rooted phylogenetic tree based on 16S rRNA gene sequence homology for species of the genera Ralstonia and Wautersia and of some species of Gramnegative non-fermenters. Cluster analysis was based on the neighbour-joining method, with Burkholderia cepacia ATCC $25416^{\top}$ (M22518) as the outgroup. Numbers at branch-points are percentages of 100 bootstrap resamplings that support the tree topology. Asterisk indicates a sequence determined during this study. Bar, $1 \%$ estimated sequence divergence.

gen. nov., and by further elucidating the taxonomy of this group of organisms.

\section{METHODS}

The type strains of species that are discussed here are listed in Table 1. Sequencing was carried out as described previously (Vaneechoutte et al., 2000) and similarity calculations and cluster analysis were carried out as described elsewhere (Nemec et al., 2001). Restriction digestion of amplified rDNA with HaeIII was carried out as described previously (Vaneechoutte et al., 1998). Phenotypic testing was carried out as described previously (De Baere et al., 2001; Laffineur et al., 2002). Fatty acid analysis was carried out as described previously (Wauters et al., 1996). DNA-DNA hybridization was carried out as described previously (Ziemke et al., 1998).

\section{RESULTS AND DISCUSSION}

\section{Rationale for the creation of Wautersia gen. nov.}

Sequence analysis of the 16S rRNA gene (Fig. 1) indicates that two distinct sublineages, with sequence dissimilarity of $>4 \%$, supported by a bootstrap value of $100 \%$, are present within the genus Ralstonia sensu lato. The Ralstonia eutropha lineage comprises $R$. basilensis, $R$. campinensis, $R$. eutropha, $R$. gilardii, $R$. metallidurans, $R$. oxalatica, $R$. paucula, $R$. respiraculi and $R$. taiwanensis, and the Ralstonia pickettii lineage comprises $R$. insidiosa, R. mannitolilytica, R. pickettii, Ralstonia solanacearum and Ralstonia syzygii comb. nov. (previously Pseudomonas syzygii). This genotypic discrimination is supported by several clear phenotypic differences (Table 2). Species of the $R$. eutropha lineage have peritrichous flagella, do not produce acids from glucose and are susceptible to colistin. In contrast, species of the $R$. pickettii lineage are characterized by the presence of one or more polar flagella in motile species, production of acid from several carbohydrates and colistin resistance. Both groups also differ in their viability on tryptic soy agar (TSA) at $25^{\circ} \mathrm{C}$ (except for $R$. syzygii, which does not grow on TSA), with 6 days viability at most for the $R$. pickettii lineage and at least 9 days for the $R$. eutropha lineage. It is proposed that species in the R. eutropha lineage should be reclassified into a novel genus, Wautersia gen. nov., a name used throughout the remainder of this manuscript.

\section{The R. pickettii lineage}

The $R$. pickettii lineage (genus Ralstonia sensu stricto) contains the species $R$. insidiosa, $R$. mannitolilytica, $R$. pickettii, $R$. solanacearum and $R$. syzygii comb. nov. A compilation of the phenotypic data gathered during this study and from the literature is given in Supplementary Table A3, which is available in IJSEM Online.

\section{R. insidiosa}

During this study, three isolates that closely resembled $R$. mannitolilytica were found, except that they did not produce acid from mannitol or D-arabitol and they were

Table 2. Phenotypic characteristics that are applicable for differentiation of the genera Ralstonia and Wautersia

\begin{tabular}{|lcc|}
\hline Characteristic & Ralstonia & Wautersia \\
\hline Flagellation & Polar, 1-4 & Peritrichous \\
Colistin $(10 \mu \mathrm{g}$ discs $)$ & Resistant & Susceptible \\
Viability on TSA at $25^{\circ} \mathrm{C}^{\star}$ & $<6$ days & $>9$ days \\
Acid production from carbohydrates & + & - \\
\hline
\end{tabular}

${ }^{\star}$ Not applicable to R. syzygii, which does not grow on TSA. 
Table 3. DNA-DNA hybridization values (\%) of closely related species obtained in this study

Species: $1, \quad R$. solanacearum LMG $2299^{\mathrm{T}} ; 2, \quad R$. syzygii LMG $10661^{\mathrm{T}} ; 3$, R. mannitolilytica LMG $6866^{\mathrm{T}} ; 4$, R. pickettii LMG $5942^{\mathrm{T}}$ (DNA group 1); 5, R. pickettii LMG 7160 (DNA group 2); 6, R. insidiosa CCUG 46389. Where two values are given, these are the results of duplicate testing.

\begin{tabular}{|c|c|c|c|c|c|c|}
\hline Species & 1 & 2 & 3 & 4 & 5 & 6 \\
\hline 1 & & $33 \cdot 7 / 45 \cdot 6$ & & & & \\
\hline 2 & $59 \cdot 0 / 22 \cdot 8$ & & & & & \\
\hline 3 & & & & $45 \cdot 4$ & $59 \cdot 7 / 39 \cdot 8$ & $35 \cdot 9$ \\
\hline 4 & & & $44 \cdot 1$ & & $77 \cdot 5 / 71 \cdot 1$ & $43 \cdot 4$ \\
\hline 5 & & & $23 \cdot 7 / 25 \cdot 5$ & $51 \cdot 7 / 44 \cdot 9$ & & $20 \cdot 4$ \\
\hline 6 & & & $37 \cdot 7$ & $35 \cdot 4$ & $37 \cdot 0$ & \\
\hline
\end{tabular}

clearly phenotypically different from both $R$. pickettii DNA groups. DNA-DNA hybridization carried out during this study (Table 3) showed clearly that this group of three phenotypically identical strains belong to an as-yetundescribed species. After submission of the first draft of this manuscript, phenotypically similar strains with nearly identical 16S rDNA sequences (see Fig. 1) were described as $R$. insidiosa (Coenye et al., 2003a). The strains of $R$. insidiosa studied here, some of which are highly clinically relevant, had one to three polar flagella, were glucolytic and were resistant to colistin; they therefore fit within the genus Ralstonia sensu stricto. The strains studied in this report produced acid from glucose and were nitratenegative, in contrast to the original description of $R$. insidiosa. Two biovars could be distinguished within $R$. insidiosa. Alkalinization/assimilation of $N$-acetylglucosamine on Simmons' agar is negative for $R$. pickettii and positive for $R$. mannitolilytica; this trait can also be used to differentiate between the two $R$. insidiosa biovars. One group (biovar 1: strains LMG $21421^{\mathrm{T}}$, CCUG 38965, CCUG 46212, CCUG 46213, CCUG 47187 and CCUG 47416) was negative for acid production, assimilation of $\mathrm{N}$-acetylglucosamine, gelatin hydrolysis and alkalinization of mucate on Simmons' base agar, whereas strains of the other group [biovar 2: strains CCUG 46387 (NF 663), CCUG 46388 (NF 882), CCUG 46389 (NF 928) and CCUG 47426] were positive for these characteristics. The first group was adipate-positive on API 20NE (bioMérieux), whereas the second group was negative for this characteristic. Reciprocal DNA-DNA hybridization values for strains LMG $21421^{\mathrm{T}}$ and CCUG 46389 were $87 \cdot 9$ and $87 \cdot 4 \%$, indicating that both biovars belong to the same species.

Remarkably, the $R$. insidiosa strains did not assimilate L-arabinose or D-xylose on minimal medium, although these carbohydrates are acidified on $\mathrm{O} / \mathrm{F}$ (oxidation/ fermentation) medium. This is not the case for R. pickettii and R. mannitolilytica, both of which assimilate and acidify L-arabinose and D-xylose. All three species acidify, but do not assimilate, maltose.

\section{R. mannitolilytica}

Several clear phenotypic differences exist between $R$. mannitolilytica (De Baere et al., 2001; Vaneechoutte et al., 2001) and other Ralstonia species. R. mannitolilytica can be differentiated from other Ralstonia species, except for Ralstonia sp. strains LMG 19089 (RAL04/MC5) and LMG 19087 (RAL07/YL13), by its assimilation/acidification of mannitol and D-arabitol. R. mannitolilytica strains also differ from $R$. pickettii and $R$. solanacearum by their resistance towards desferrioxamine and from $R$. pickettii by their lack of alkalinization of tartrate and of nitrate reductase.

\section{R. pickettii}

Historically, $R$. pickettii was created for a group of clinical isolates (Ralston et al., 1973) and also comprised strains in CDC group Va-2 (Tatum et al., 1974; Riley \& Weaver, 1975). CDC groups Va-2 and Va-1 were regarded as two different biovars of $R$. pickettii (Pickett \& Greenwood, 1980; referred to as Pseudomonas pickettii). In a previous study (De Baere et al., 2001), it has been shown that two DNA groups could be distinguished, based on both $16 \mathrm{~S}$ rDNA sequencing and DNA-DNA hybridization.

The DNA groups differed at positions 256 and 266 (Escherichia coli numbering; Woese et al., 1983), with strains of DNA group 1 having the nucleotides $\mathrm{A}$ and $\mathrm{T}$ at those positions, whereas strains of DNA group 2 have $G$ and C (see Supplementary Table A2 in IJSEM Online). By using restriction of the amplified 16S rRNA gene with HaeIII, these DNA groups could be distinguished quickly (see column A in Supplementary Table A1 in IJSEM Online). Although it has been reported that correspondence was observed between genotypic groups and biovars, these findings were not reproduced in this study. In this study, extensive attempts to confirm the differential acidification of glucose and maltose in isolates of $R$. pickettii biovars Va-1 and Va-2 failed and turned out to be quantitative rather than qualitative (Supplementary Table A1, available in IJSEM Online). Aside from the classical O/F medium (Hugh \& Leifson, 1953), phenol red low-peptone agar was used in slants, as described for acidification of ethylene glycol (Wauters et al., 1998), replacing ethylene glycol by $1 \%(\mathrm{w} / \mathrm{v})$ lactose or maltose. Low-peptone medium is usually more sensitive to acidification than classical O/F medium. Reproducibility of the tests was only moderate; this can possibly be explained in part by the low nutritional content of $\mathrm{O} / \mathrm{F}$ medium, which limits the growth of isolates of a species such as $R$. pickettii. Differences in inoculum freshness and density may, therefore, strongly influence the speed of physiological reactivity. In our hands, it proved impossible to delineate the biovars unambiguously on the basis of lactose and maltose acidification, due to the high variability observed and the absence of a clear gap between slow and rapid reactivity.

Despite further extensive screening of biochemical characteristics, no clear-cut, unambiguous differentiation was 
possible between the two DNA groups. Therefore, it is suggested that the biovar designations should no longer be used. There is no association between DNA groups and the former biovar designations, in contrast to our previous results (De Baere et al., 2001). In this study, DNA-DNA hybridization was repeated by using the method of Ziemke et al. (1998) and a lack of reciprocity for the data was found: when DNA group 1 strain LMG 7160 was labelled, the values obtained for replicate testing of DNA-DNA hybridization with a strain of DNA group 2 were $77 \cdot 1$ and $77 \cdot 5 \%$, whereas reciprocal hybridization with DNA group 2 strain CCUG $6389^{\mathrm{T}}$ as the labelled strain resulted in values of $44 \cdot 9$ and $51 \cdot 7 \%$ (Table 3 ).

\section{R. solanacearum}

$R$. solanacearum strains tested in this study could be differentiated from other Ralstonia species by acidification/ assimilation of sucrose, lack of pyrrolidonyl arylamidase and assimilation of caprate, malonate, propionate, suberate, acetate and lactate. $R$. solanacearum has been described as non-motile (Coenye et al., 1999; De Baere et al., 2001) and the two strains studied here were non-motile and no flagella were observed; however, other sources mention the presence of one to four polar flagella (Krieg \& Holt, 1984; Tans-Kersten et al., 2001) and of flagellin genes and the occasional observation of high motility in culture (Tans-Kersten et al., 2001). Tans-Kersten et al. (2001) showed that only $1-10 \%$ of the cell population is flagellated at times, which possibly explains several studies that have reported the absence of flagellation. It is concluded that $R$. solanacearum strains have polar flagella, as observed in strains of other Ralstonia species.

\section{R. syzygii}

$R$. syzygii comb. nov. has been recognized previously by others as a genuine Ralstonia species, rather than being a member of the genus Pseudomonas (Seal et al., 1993; Taghavi et al., 1996; Anzai et al., 2000). In a previous study (De Baere et al., 2001), it was shown that the 16S rRNA gene sequences obtained for $R$. syzygii strains LMG 6969, LMG 6970, LMG $10661^{\mathrm{T}}$ and LMG 10662 clustered with the $R$. solanacearum GenBank sequence (accession no. X67036) with > $99 \%$ similarity. In this study, DNA-DNA hybridization indicated that $R$. solanacearum and $R$. syzygii are clearly two separate species (Table 3 ). Based on these combined data, it is proposed that Pseudomonas syzygii is renamed Ralstonia syzygii comb. nov.

\section{Emended description of Ralstonia insidiosa Coenye et al. 2003}

Ralstonia insidiosa (in.si.di.o'sa. L. fem. adj. insidiosa deceitful, dangerous, referring to the fact that these seemingly harmless environmental organisms can be isolated from, and possibly cause infections in, humans).

The description is based on the data of Coenye et al. (2003a) and this study. Cells are Gram-negative, non-sporulating, aerobic, non-fermentative, motile rods with one to three polar flagella. Aerobic growth is observed at 28, 32 and $37^{\circ} \mathrm{C}$ and on Burkholderia cepacia-selective agar. Catalase, oxidase, lipase, phosphatase, proline aminopeptidase, pyrrolidonyl aminopeptidase and $\gamma$-L-glutamyl aminopeptidase activities are present. However, alkaline phosphatase is negative when Rosco tablets are used. No lysine decarboxylase, arginine dihydrolase, gelatinase, $\alpha$-glucosidase, $\beta$-glucosidase, tryptophan aminopeptidase or $\mathrm{N}$-benzylarginine aminopeptidase activities are detected. Indole is not produced. No acid is produced from sucrose or mannitol. The original description (Coenye et al., 2003a) mentions a lack of acid production from glucose, but in this study, oxidative acid production was observed from glucose, L-arabinose and xylose. Acid production from lactose is variable. Glucose, gluconate, caprate, adipate, malate and citrate are assimilated, but L-arabinose, mannose, mannitol and maltose are not. Alkalinization occurs on minimal mineral agar with acetate, allantoin, lactate and malonate, but not with galacturonate, oxalate or maleate. Nitrate reduction is negative. Resistant to colistin and desferrioxamine. Two biovars can be distinguished: strains of biovar 1 are negative for acid production from and assimilation of $\mathrm{N}$-acetylglucosamine, gelatin hydrolysis and mucate on Simmons' base agar and positive for adipate on API 20NE; biovar 2 strains have the opposite characteristics. DNA G $+\mathrm{C}$ content is $63 \cdot 9-64 \cdot 3 \mathrm{~mol} \%$.

The type strain is LMG $21421^{\mathrm{T}}\left(=\mathrm{CCUG} 46789^{\mathrm{T}}\right)$, which was isolated from the sputum of a patient with acute lymphoblastic leukaemia in the USA in 2001. Its DNA G + C content is $64.3 \mathrm{~mol} \%$. Phenotypic characteristics are the same as described above for the species. The type strain has no urease activity, does not assimilate $\mathrm{N}$-acetylglucosamine and assimilates phenylacetate. The GenBank accession number for the $16 \mathrm{~S}$ rRNA gene sequence of the type strain is AF488779.

\section{Description of Ralstonia syzygii (Roberts et al. 1990) comb. nov.}

Basonym: Pseudomonas syzygii Roberts et al. 1990.

Ralstonia syzygii (sy.zy'gi.i. N.L. n. Syzygium generic name of the clove tree; L. gen. n. syzygii of the genus Syzygium).

The description is based on the data of Roberts et al. (1990b), De Baere et al. (2001) and this study. Gramnegative, non-sporulating, non-capsulated, non-motile, straight rods with rounded ends $(0.5-0.6 \times 1 \cdot 0-2.5 \mu \mathrm{m})$ that occur singly, in pairs or occasionally in short chains. Aerobic. Growth is poor (colonies of $<1 \mathrm{~mm}$ after 7 days) or absent on many common bacteriological media. Good growth (colonies up to $5 \mathrm{~mm}$ after 7-12 days) occurs on the following iron salts-containing media: buffered charcoal yeast extract agar, Periwinkle wilt medium and iron-supplemented casamino acids medium. Growth on complex media is accompanied by a rise in $\mathrm{pH}$. Optimum 
temperature for growth is around $28{ }^{\circ} \mathrm{C}$. No growth occurs at 4 or $37^{\circ} \mathrm{C}$. Resistant to colistin and susceptible to desferrioxamine. All strains are oxidase- and catalasepositive, grow at $\mathrm{pH} 6 \cdot 0-7 \cdot 5$ and utilize fumarate, DLmalate, pyruvate and succinate. All strains are negative for levan, arginine dihydrolase and lecithinase, do not hydrolyse aesculin or starch, do not grow in the presence of $1 \%$ $\mathrm{NaCl}$ and do not utilize $p$-alanine, L-arginine, L-cysteine, glycine, L-leucine, L-lysine, L-methionine, L-phenylalanine, DL-serine, L-threonine, L-trytophan, L-valine, L-arabinose, D-cellobiose, D-galactose, lactose, maltose, D-mannose, D-raffinose, D-rhamnose, D-ribose, D-xylose, acetate, DL-lactate, D-tartrate, $m$-erythritol, glycerol, mannitol or sorbitol. Most strains ( $>85 \%$ ) grow at $\mathrm{pH} 5 \cdot 0$ and utilize L-aspartate, L-glutamate, L-tyrosine, D-glucose and sucrose. Variable results are obtained for tyrosinase activity, growth on $0.5 \% \mathrm{NaCl}$ at $\mathrm{pH} 8.0$, utilization of L-asparagine, L-histidine, fructose, citrate and 2-oxoglutarate and nitrate reduction. All strains possess alkaline and acid phosphatases, esterase, esterase lipase, leucine arylamidase and naphthol-AS-BI-phosphohydrolase, but do not possess trypsin, chymotrypsin, $\alpha$ - or $\beta$-galactosidases, $\beta$-glucuronidase, $\alpha$ - or $\beta$-glucosidases, $N$-acetyl- $\beta$-glucosamidase, $\alpha$ mannosidase or $\alpha$-fucosidase, as determined by API ZYM test strips. Major cellular fatty acids are $\mathrm{C}_{14: 0}, \mathrm{C}_{14: 0} 3-\mathrm{OH}$, $\mathrm{C}_{16: 1} \omega 9 c, \mathrm{C}_{16: 0}, \mathrm{C}_{17: 0}$ cyclo, $\mathrm{C}_{18: 1} \omega 11 c, \mathrm{C}_{19: 0}$ cyclo and $\mathrm{C}_{18: 1}$ 2-0H. DNA G $+\mathrm{C}$ content is $66-67 \mathrm{~mol} \%$ (buoyant density method).

The type strain is R001 $^{\mathrm{T}}\left(=\right.$ ATCC $49453^{\mathrm{T}}=\mathrm{LMG} 10661^{\mathrm{T}}$ $=$ NCPPB $\left.3446^{\mathrm{T}}\right)$. Isolated as a phytopathogen from xylem tissues of the clove tree (Syzygium aromaticum) and other Syzygium spp., and from insect vectors (Hindola spp.) in Indonesia. The GenBank accession number of the $16 \mathrm{~S}$ rRNA gene sequence of the type strain is $\mathrm{AB} 021403$.

\section{The $R$. eutropha lineage (Wautersia gen. nov.)}

The R. eutropha lineage (Wautersia gen. nov.) contains the species Wautersia basilensis, Wautersia campinensis, Wautersia eutropha, Wautersia gilardii, Wautersia metallidurans, Wautersia oxalatica, Wautersia paucula, Wautersia respiraculi and Wautersia taiwanensis. Phenotypic data gathered during this study and from the literature are listed in Supplementary Table A3 (available in IJSEM Online).

\section{Description of Wautersia gen. nov.}

Wautersia (Wau.ter'si.a. L. fem. n. Wautersia named in honour of the Belgian microbiologist Georges Wauters).

Gram-negative rods that are motile by means of peritrichous flagella. Aerobic. Forms smooth colonies that reach 1-2 mm within $48 \mathrm{~h}$ at $30^{\circ} \mathrm{C}$ on blood agar. Positive for catalase and oxidase. Glucose is neither acidified nor assimilated. Susceptible to colistin. Cellular fatty acids are of the saturated and monounsaturated straight-chain types, mainly $\mathrm{C}_{16: 1} \omega 9 c, \mathrm{C}_{16: 0}, \mathrm{C}_{18: 1} \omega 11 c$ and $\mathrm{C}_{14: 0}$. The type species of the genus is Wautersia eutropha.

\section{Wautersia basilensis (Steinle et al. 1998) comb. nov.}

W. basilensis (Steinle et al., 1998) is the only Wautersia species that is susceptible to desferrioxamine. Like $W$. paucula, it does not alkalinize allantoin and, unlike most other Wautersia species, it does not alkalinize oxalate.

\section{Wautersia eutropha (Davis 1969) Yabuuchi et al. 1996 comb. nov.}

W. eutropha (Yabuuchi et al., 1995) can be differentiated from other Wautersia species by its ability to assimilate L-serine, $\mathrm{N}$-acetylglucosamine and 2-ketogluconate and its inability to alkalinize mucate on Simmons' agar base.

\section{Wautersia gilardii (Coenye et al. 1999) comb. nov.}

W. gilardii (Coenye et al., 1999) can be distinguished from $W$. paucula by its lack of urease and Tween esterase activities, from $W$. eutropha by alkalinization of mucate and lack of assimilation of $\mathrm{N}$-acetylglucosamine, L-serine and 2-ketogluconate, and from W. basilensis by resistance to desferrioxamine, alkalinization of allantoin and assimilation of phenylacetate.

\section{Wautersia paucula (Vandamme et al. 1999) comb. nov.}

In a previous study (De Baere et al., 2001), it was shown that the available $16 \mathrm{~S}$ rDNA sequences of Ralstonia group CDC IVc-2 strains [GenBank accession nos AF098288 (Moissenet et al., 1999) and AF067657 (Osterhout et al., 1998)] were identical to that of $W$. paucula (Vandamme et al., 1999; accession no. AF085226). W. paucula strains differ from both $W$. eutropha and W. gilardii by strong urease production and a lack of alkalinization of allantoin, from $W$. gilardii by marked Tween esterase activity and from $W$. eutropha by alkalinization of mucate and absence of assimilation of $\mathrm{N}$-acetylglucosamine, L-serine and 2-ketogluconate. It differs from $W$. basilensis by resistance to desferrioxamine and Tween esterase activity.

\section{Wautersia campinensis (Goris et al. 2001) comb. nov., Wautersia metallidurans (Goris et al. 2001) comb. nov., Wautersia oxalatica (ex Khambata and Bhat 1953) Sahin et al. 2000 comb. nov., Wautersia respiraculi (Coenye et al. 2003) comb. nov. and Wautersia taiwanensis (Chen et al. 2001) comb. nov.}

The newly described species $W$. campinensis, W. metallidurans, $W$. oxalatica, $W$. respiraculi and $W$. taiwanensis cluster in the genus Wautersia, according to their 16S rRNA gene sequences (Fig. 1). From the literature (Sahin et al., 2000; Chen et al., 2001; Goris et al., 2001; Coenye et al., 2003b), it 
is clear that where characteristics useful for the differentiation of Ralstonia and Wautersia species were given, i.e. flagellation, sugar acidification and colistin susceptibility, these indicated that the species should be classified as Wautersia species. The following characteristics were tested in this study: flagellation, acid production from carbohydrates, colistin susceptibility and survival at room temperature on solid agar (except for $W$. respiraculi). It was confirmed that the characteristics of these species corresponded with those that were determined previously as being characteristic of the genus Wautersia (Table 2).

\section{Description of Wautersia basilensis (Steinle et al. 1998) comb. nov.}

Basonym: Ralstonia basilensis Steinle et al. 1998.

Wautersia basilensis (ba.si.len' sis. L. fem. adj. basilensis from Basilea (Basel, Switzerland), where the strain was isolated).

The description is based on the data of Steinle et al. (1998) and this study. Cells are short rods $(0 \cdot 8 \times 1 \cdot 2-2 \cdot 2 \mu \mathrm{m})$ that occur singly, in pairs or in short chains, are motile by means of peritrichous flagella and form round (sometimes with a slightly scalloped margin), smooth, convex and transparent colonies of about $0.5 \mathrm{~mm}$ diameter after $24 \mathrm{~h}$ incubation on TSA at $30^{\circ} \mathrm{C}$. Oxidase- and catalase-positive. Aerobic growth occurs at $4,20,30$ and $37^{\circ} \mathrm{C}$, but no growth is detected at $41{ }^{\circ} \mathrm{C}$. Variable for nitrate reduction, but no nitrite reduction occurs. No indole is produced from tryptophan. Urease activity is delayed. No acid is produced from glucose. Enzyme activities detected are: alkaline phosphatase, esterase (C4), esterase lipase (C8), leucine arylamidase, acid phosphatase (weak) and naphtholAS-BI-phosphohydrolase. Enzyme activities that are not detected are: arginine dihydrolase, $\alpha$-glucosidase, protease, $\beta$-galactosidase, lipase (C14), valine arylamidase, cystine arylamidase, trypsin, $\alpha$-chymotrypsin, $\alpha$-galactosidase, $\beta$ glucuronidase, $\beta$-glucosidase, $N$-acetyl- $\beta$-glucosaminidase, $\alpha$-mannosidase and $\alpha$-fucosidase. Assimilates D-gluconate, caprate, adipate, L-malate, citrate and phenylacetate. Does not assimilate D-glucose, L-arabinose, D-mannose, Dmannitol, $\mathrm{N}$-acetyl-D-glucosamine or maltose. Susceptible to colistin and desferrioxamine. DNA $\mathrm{G}+\mathrm{C}$ content is $65 \cdot 0-65 \cdot 5 \mathrm{~mol} \%$. Major fatty acid components are $\mathrm{C}_{14: 0}$ $(4 \cdot 5 \%), \mathrm{C}_{16: 0}(20 \cdot 6 \%), \mathrm{C}_{17: 0}$ cyclo $(1 \cdot 3 \%), \mathrm{C}_{18: 1} \omega 7 \mathrm{c}$ $(24 \cdot 7 \%), \mathrm{C}_{16: 1} \quad 2-\mathrm{OH}(1 \cdot 8 \%), \mathrm{C}_{18: 1} \quad 2-\mathrm{OH} \quad(4 \cdot 8 \%)$, summed feature $2(9 \pm 0 \%)$ and summed feature 3 $(32 \pm 9 \%)$.

The type strain is $\mathrm{RK}^{\mathrm{T}}\left(=\mathrm{DSM} 11853^{\mathrm{T}}=\mathrm{LMG} 18990^{\mathrm{T}}\right.$ $=\mathrm{LMG} 19474^{\mathrm{T}}=\mathrm{DSM} 11853^{\mathrm{T}}$ ), which was isolated from a freshwater pond sediment at Amponville, France, after enrichment in a fixed-bed reactor with 2,6-dichlorophenol as the sole carbon and energy source. Its DNA G $+\mathrm{C}$ content is $65.0 \mathrm{~mol} \%$ and its phenotypic characteristics are as described above for the species. The GenBank accession number of the $16 \mathrm{~S}$ rRNA gene sequence of the type strain is $\mathrm{AF} 312022$.

\section{Description of Wautersia campinensis (Goris et al. 2001) comb. nov.}

Basonym: Ralstonia campinensis Goris et al. 2001.

Wautersia campinensis (cam.pin.en'sis. L. fem. adj. campinensis of the Kempen or Campine, the geographical region of north-east Belgium where the strains were originally isolated).

The description is based on the data of Goris et al. (2001) and this study. Cells are short rods $(0 \cdot 8 \times 1 \cdot 2-1 \cdot 8 \mu \mathrm{m})$ that occur singly, in pairs or in short chains, are motile by means of peritrichous flagella and form round (sometimes with a slightly scalloped margin), smooth, convex and transparent colonies of about $0.5 \mathrm{~mm}$ diameter after $24 \mathrm{~h}$ incubation on TSA at $30^{\circ} \mathrm{C}$. Oxidase- and catalase-positive. Aerobic growth occurs at 20,30, 37 and $41{ }^{\circ} \mathrm{C}$, but not at $4{ }^{\circ} \mathrm{C}$. Nitrate is reduced, but nitrite is not. No indole is produced from tryptophan. No acid is produced from glucose. Enzyme activities detected are: urease, alkaline phosphatase, esterase (C4), esterase lipase (C8), leucine arylamidase, valine arylamidase, acid phosphatase and naphthol-AS-BI-phosphohydrolase. Enzyme activities that are not detected are: arginine dihydrolase, protease, $\beta$-galactosidase, lipase (C14), cystine arylamidase, trypsin, $\alpha$-chymotrypsin, $\alpha$-galactosidase, $\beta$-glucuronidase, $\beta$ glucosidase, $N$-acetyl- $\beta$-glucosaminidase, $\alpha$-mannosidase and $\alpha$-fucosidase. $\alpha$-Glucosidase is variable. Assimilates D-gluconate, caprate, adipate, L-malate and phenylacetate. No assimilation of D-glucose, L-arabinose, D-mannose, D-mannitol, $\mathrm{N}$-acetyl-D-glucosamine, maltose or citrate. Major fatty acid components are $\mathrm{C}_{14: 0}(5.0 \%), \mathrm{C}_{16: 0}$ $(24 \cdot 6 \%), \mathrm{C}_{17: 0}$ cyclo $(6 \cdot 1 \%), \mathrm{C}_{18: 0}(1 \cdot 5 \%), \mathrm{C}_{18: 1} \omega 7 c$ $(19 \cdot 5 \%), \mathrm{C}_{14: 0} \quad 2-\mathrm{OH} \quad(2 \cdot 1 \%), \mathrm{C}_{18: 1} \quad 2-\mathrm{OH} \quad(2 \cdot 7 \%)$, summed feature $2(8 \cdot 9 \%)$ and summed feature $3(28 \cdot 4 \%)$.

The type strain is $\mathrm{WS}^{\mathrm{T}}\left(=\mathrm{LMG} 19282^{\mathrm{T}}=\right.$ CCUG $\left.44526^{\mathrm{T}}\right)$, which was isolated from a zinc-desertified area in Lommel, Belgium. Its DNA $\mathrm{G}+\mathrm{C}$ content is $66.6 \mathrm{~mol} \%$ and its phenotypic characteristics are as described above for the species. The GenBank accession number of the 16S rRNA gene sequence of the type strain is AF312020.

\section{Description of Wautersia eutropha (Davis 1969) Yabuuchi et al. 1996 comb. nov.}

Basonym: Alcaligenes eutrophus Davis 1969.

The description is based on the data of Yabuuchi et al. (1995) and De Baere et al. (2001). Gram-negative, nonsporulating rods that are motile by means of peritrichous flagella. Grows aerobically at 30 and $37^{\circ} \mathrm{C}$ on TSA. Catalaseand oxidase-positive. Nitrate is reduced. Urease may be produced upon exhaustion of other nitrogen sources. Indole is not produced. Gelatin and aesculin are not hydrolysed. No decarboxylation of lysine and ornithine occurs. No arginine dihydrolase activity. No acidification or assimilation of glucose occurs. Susceptible to colistin and resistant to desferrioxamine. Alkaline phosphatase and 
pyrrolidone peptidase are positive. The main cellular fatty acids are $\mathrm{C}_{18: 1}, \mathrm{C}_{16: 0}, \mathrm{C}_{16: 1}, \mathrm{C}_{17: 0}$ cyclo and $\mathrm{C}_{14: 0}$.

The type strain is ATCC $17697^{\mathrm{T}}$ (=CCUG $1776^{\mathrm{T}}=\mathrm{DSM}$ $531^{\mathrm{T}}=\mathrm{LMG} 1199^{\mathrm{T}}$ ). Its $\mathrm{G}+\mathrm{C}$ content is $66 \cdot 5 \mathrm{~mol} \%$. The GenBank accession number of the 16S rRNA gene sequence of the type strain is M32021.

\section{Description of Wautersia gilardii (Coenye et al. 1999) comb. nov.}

Basonym: Ralstonia gilardii Coenye et al. 1999.

Wautersia gilardii (gi.lar'di.i. N.L. gen. n. gilardii in honour of G. L. Gilardi, an American microbiologist).

The description is based on the data of Coenye et al. (1999), De Baere et al. (2001) and Wauters et al. (2001). Gramnegative, non-sporulating rods that are motile by means of peritrichous flagella. This was shown clearly by Wauters et al. (2001), in contrast to a previous report by Coenye et al. (1999) that reported polar flagellation. Aerobic growth occurs at 30,37 and $42^{\circ} \mathrm{C}$. Catalase- and oxidasepositive. Nitrate reduction is variable. No denitrification occurs. No urease, $\beta$-galactosidase or DNase activities are detected. No liquefaction of gelatin or hydrolysis of aesculin occurs. Indole is not produced. No acidification or assimilation of carbohydrates occurs. Positive for alkaline phosphatase (Rosco) and weakly positive for pyrrolidonyl arylamidase. Susceptible to colistin and resistant to desferrioxamine. The main fatty acid components are: $\mathrm{C}_{14: 0}, \mathrm{C}_{16: 0}, \mathrm{C}_{17: 0}$ cyclo, $\mathrm{C}_{18: 0}, \mathrm{C}_{16: 1} \omega 7 c, \mathrm{C}_{16: 0} 2-\mathrm{OH}$ and $\mathrm{C}_{19: 0} \omega 8 c$ cyclo. DNA $\mathrm{G}+\mathrm{C}$ content is between 68 and $69 \mathrm{~mol} \%$.

The type strain is Gilardi $4325^{\mathrm{T}} \quad\left(=\right.$ ATCC $700815^{\mathrm{T}}$ $=$ CCUG $38401^{\mathrm{T}}=$ LMG $5886^{\mathrm{T}}$ ), which was isolated from a whirlpool. The DNA G+C content of the type strain is $68.3 \mathrm{~mol} \%$. The GenBank accession number of the $16 \mathrm{~S}$ rRNA gene of the type strain is AF076645.

\section{Description of Wautersia metallidurans (Goris et al. 2001) comb. nov.}

Basonym: Ralstonia metallidurans Goris et al. 2001.

Wautersia metallidurans (me.tal.li.du'rans. L. n. metallum metal; L. pres. part. durans enduring; N.L. part. adj. metallidurans enduring metal, from the fact that these strains are able to survive high heavy-metal concentrations).

The description is based on the data of Goris et al. (2001) and this study. Cells are short rods $(0 \cdot 8 \times 1 \cdot 2-2 \cdot 2 \mu \mathrm{m})$ that occur singly, in pairs or in short chains, are motile by means of peritrichous flagella and form round (sometimes with a slightly scalloped margin), smooth, flat, convex and transparent colonies of about $0.5 \mathrm{~mm}$ diameter after $24 \mathrm{~h}$ incubation on TSA at $30^{\circ} \mathrm{C}$. Oxidase- and catalase-positive. Aerobic growth occurs at 20,30 and $37^{\circ} \mathrm{C}$, but no growth is detected at 4 or $41^{\circ} \mathrm{C}$. Reduction of nitrate and nitrite is variable. No indole is produced from tryptophan. No acid is produced from glucose. Enzyme activities detected are: alkaline phosphatase, esterase (C4), esterase lipase (C8), leucine arylamidase, valine arylamidase, acid phosphatase and naphtholAS-BI-phosphohydrolase. Enzyme activities that are not detected: arginine dihydrolase, $\alpha$-glucosidase, protease, $\beta$-galactosidase, lipase (C14), cystine arylamidase, trypsin, $\alpha$-chymotrypsin, $\alpha$-galactosidase, $\beta$-glucuronidase, $\beta$-glucosidase, $N$-acetyl- $\beta$-glucosaminidase, $\alpha$-mannosidase and $\alpha$-fucosidase. Urease activity can be weak or absent. Assimilates D-gluconate, adipate and L-malate. Assimilation of caprate, citrate and phenylacetate is variable. No assimilation of D-glucose, L-arabinose, D-mannose, D-mannitol, $\mathrm{N}$-acetyl-D-glucosamine or maltose occurs. DNA G+C content is $63 \cdot 7-63 \cdot 9 \mathrm{~mol} \%$. Major fatty acid components are $\mathrm{C}_{14: 0}(4 \cdot 4 \%), \mathrm{C}_{16: 0}(20 \cdot 9 \%), \mathrm{C}_{17: 0}$ cyclo $(3 \cdot 2 \%)$, $\mathrm{C}_{18: 1} \omega 7 \mathrm{c}(19 \cdot 8 \%), \mathrm{C}_{16: 0} \quad 2-\mathrm{OH}(3 \cdot 3 \%), \mathrm{C}_{18: 1} \quad 2-\mathrm{OH}$ $(1 \cdot 4 \%)$, summed feature $2(11 \cdot 3 \%)$ and summed feature $3(34 \cdot 2 \%)$.

The type strain is $\mathrm{CH} \quad 34^{\mathrm{T}} \quad\left(=\mathrm{CIP} \quad 107179^{\mathrm{T}}=\mathrm{DSM}\right.$ $2839^{\mathrm{T}}=\mathrm{LMG} 1195^{\mathrm{T}}$ ), which was isolated from the wastewater of a zinc factory at Liège, Belgium. Its DNA G $+\mathrm{C}$ content is $63 \cdot 7 \mathrm{~mol} \%$. The GenBank accession number of the 16S rRNA gene of the type strain is Y10824.

\section{Description of Wautersia oxalatica (ex Khambata and Bhat 1953) Sahin et al. 2000, comb. nov.}

Basonym: Pseudomonas oxalaticus Khambata and Bhat 1953.

Wautersia oxalatica (o.xa.la'ti.ca. N.L. fem. adj. oxalatica pertaining to oxalate).

The description is based on the data of Sahin et al. (2000) and this study. Gram-negative, non-sporulating, aerobic, short rods $(0.3-0.4 \times 0.9-1.5 \mu \mathrm{m})$ that are motile with peritrichous flagella. Colonies are cream-coloured and no carotenoid pigment is produced. Catalase- and oxidasepositive. Optimum growth with oxalate is at $\mathrm{pH} 6.6$ at $25^{\circ} \mathrm{C}$. In liquid culture, doubling time with oxalate is $4 \cdot 5 \mathrm{~h}$. Unable to grow autotrophically with hydrogen. Assimilation of oxalate follows the glycolate pathway. Organic acids, except tartrate and aconitate, are used as carbon sources. Nitrate is reduced to nitrite. Urea is hydrolysed, but casein, starch and gelatin are not. Indole and hydrogen sulphide are not produced. Grows well on lactate and formate, but not on glucose. Able to use phenol, ethanol and ethylene glycol as carbon sources. Susceptible to colistin.

The type strain is Ox $1^{\mathrm{T}}$ (=ATCC $11883^{\mathrm{T}}=$ CCUG $2086^{\mathrm{T}}=$ DSM $1105^{\mathrm{T}}=$ LMG $\left.2235^{\mathrm{T}}\right)$, which was isolated from the alimentary tract of an Indian earthworm. Its DNA G $+\mathrm{C}$ content is $68 \mathrm{~mol} \%$ ( $T_{\mathrm{m}}$ method) or $67 \%$ (buoyant density method). The GenBank accession number of the 16S rRNA gene sequence of the type strain is AF155567. 


\section{Description of Wautersia paucula (Vandamme et al. 1999) comb. nov.}

Basonym: Ralstonia paucula Vandamme et al. 1999.

Wautersia paucula (pau'cu.la. L. fem. adj. paucula rare, very few, to indicate that these strains only cause human infections sporadically).

The description is based on the data of Vandamme et al. (1999) and De Baere et al. (2001). Gram-negative, nonsporulating and rod-shaped. Cells are about $0 \cdot 8 \times 1 \cdot 2$ $2 \cdot 0 \mu \mathrm{m}$ after $24 \mathrm{~h}$ growth on TSA at $30^{\circ} \mathrm{C}$. Motile by means of peritrichous flagella. Strains produce convex, circular, non-pigmented colonies with an entire edge and a smooth surface. Catalase- and oxidase-positive. No haemolysis occurs on horse blood agar. Aerobic growth occurs at 30, 37 and $42{ }^{\circ} \mathrm{C}$. No acid is produced from D-glucose, maltose, adonitol, D-fructose or D-xylose. Grows in the presence of 0.5 and $1.5 \% \mathrm{NaCl}$, but not in the presence of cetrimide, $10 \%$ lactose, penicillin (10 $\mu \mathrm{g}$ discs), or $3,4 \cdot 5$ or $6 \% \mathrm{NaCl}$. Susceptible to colistin. Grows on Drigalski agar. Hydrolyses Tween 80 . No fluorescence occurs on King B medium. Negative for lysine and ornithine decarboxylases and arginine dihydrolase activities. No amylase activity is detected. No reduction of nitrate or nitrite. Hydrolysis of urea, but not of gelatin or aesculin, occurs. No $\beta$ galactosidase or DNase activities are detected. Indole is not produced. No production of hydrogen sulfide or acid occurs in triple-sugar iron agar. No tryptophanase activity is detected. Assimilates D-gluconate, caprate, adipate, L-malate, citrate, phenylacetate and DL-lactate, but not Dglucose, trehalose, L-arginine, DL-norleucine, L-arabinose, D-mannose, D-mannitol, $N$-acetyl-D-glucosamine, maltose or sucrose. Alkaline and acid phosphatase, esterase $\mathrm{C} 4$, ester lipase C8, lipase C14, leucine, cystine and pyrrolidonyl arylamidases and phosphoamidase are present. However, alkaline phosphatase is variable when Rosco tablets are used. Valine arylamidase, trypsin, chymotrypsin, $\alpha$-galactosidase, $\beta$-glucuronidase, $\alpha$ - and $\beta$-glucosidase, $N$-acetyl- $\beta$-glucosaminidase, $\beta$-mannosidase and $\beta$ fucosidase activities are not detected. Isolated from a variety of human clinical sources including blood, wounds, sputum, urine, eye, throat and peritoneal fluid, as well as pool water, groundwater and bottled mineral water. DNA $\mathrm{G}+\mathrm{C}$ content is $65-67 \mathrm{~mol} \%$.

The type strain is ATCC $700817^{\mathrm{T}}$ ( = CCUG $12507^{\mathrm{T}}=\mathrm{LMG}$ $3244^{\mathrm{T}}$ ), which was isolated from a human respiratory tract in the USA. Its DNA G $+\mathrm{C}$ content is $67 \mathrm{~mol} \%$. The GenBank accession number of the $16 \mathrm{~S}$ rRNA gene sequence of strain LMG 3413 is AF085226. The sequence of the type strain has apparently not been submitted to GenBank.

\section{Description of Wautersia respiraculi (Coenye et al. 2003) comb. nov.}

Basonym: Ralstonia respiraculi Coenye et al. 2003.

Wautersia respiraculi (re.spi.ra'cu.li. L. n. respiraculum breathing, respiration; L. gen. n. respiraculi of the respiratory system).

The description is based on the data of Coenye et al. (2003b). Gram-negative, non-fermentative, non-sporulating, motile rods. Growth is observed at 28,32 and $37^{\circ} \mathrm{C}$. Catalase- and oxidase-positive. No lysine decarboxylase, urease, $\beta$-galactosidase or lipase activities are detected. No indole is produced. No acid is produced from glucose, sucrose or lactose in $\mathrm{O} / \mathrm{F}$ medium. Assimilates gluconate, caprate, adipate and malate, but not glucose, arabinose, mannose, mannitol, $\mathrm{N}$-acetylglucosamine, maltose, citrate or phenylacetate. The following fatty acids are present: $\mathrm{C}_{14: 0}, \mathrm{C}_{14: 0} 3-\mathrm{OH}, \mathrm{C}_{16: 1} \omega 7 c, \mathrm{C}_{16: 0}, \mathrm{C}_{17: 0}$ cyclo, $\mathrm{C}_{16: 0}$ $2-\mathrm{OH}, \mathrm{C}_{18: 1} \omega 7 c$ and $\mathrm{C}_{18: 1} 2-\mathrm{OH}$.

The type strain is $\mathrm{AU} 3313^{\mathrm{T}}$ (=CCUG $46809^{\mathrm{T}}=\mathrm{LMG}$ $21510^{\mathrm{T}}$ ), which was isolated from the sputum of a person with cystic fibrosis in the USA in 2001. Phenotypic characteristics are the same as described above for the species. In addition, the type strain has phosphatase and $\alpha$-glucosidase activities and reduces nitrate, but is lipasenegative. The GenBank accession number for the 16S rRNA gene sequence of the type strain is AF500583.

\section{Description of Wautersia taiwanensis (Chen et al. 2001) comb. nov.}

Basonym: Ralstonia taiwanensis Chen et al. 2001.

Wautersia taiwanensis (tai.wan.en'sis. N.L. fem. adj. taiwanensis of Taiwan, where the root nodule strains were isolated).

The description is based on the data of Chen et al. (2001) and this study. Gram-negative, non-sporulating and rodshaped; cells are about $0 \cdot 5-0.7 \times 0 \cdot 8-2 \cdot 0 \mu \mathrm{m}$ after $24 \mathrm{~h}$ growth on TSA at $30^{\circ} \mathrm{C}$. Motile by means of peritrichous flagella. Aerobic growth is observed at 28,30 and $37^{\circ} \mathrm{C}$. Catalase- and oxidase-positive. Nitrate is reduced. Aesculin is hydrolysed. Susceptible to colistin. No urease, $\beta$ galactosidase or DNase activities are detected. No indole is produced. No acid is produced from glucose. No autotrophic growth occurs. DNA G $+\mathrm{C}$ content is about $67 \mathrm{~mol} \%$. Isolated from root nodules of Mimosa pudica and Mimosa diplotricha and from sputum of a cystic fibrosis patient.

The type strain is $\mathrm{R}^{\mathrm{T}}$ (= CCUG $44338^{\mathrm{T}}=\mathrm{LMG} 19424^{\mathrm{T}}$ ), which was isolated from a root nodule of Mimosa pudica. Its DNA $\mathrm{G}+\mathrm{C}$ content is $67 \cdot 3 \mathrm{~mol} \%$. The GenBank accession number of the $16 \mathrm{~S}$ rRNA gene of the type strain is AF300324.

\section{ACKNOWLEDGEMENTS}

We thank Gundula Will, Leen Van Simaey, Catharine De Ganck and Inge Bocquaert for excellent technical assistance. 


\section{REFERENCES}

Anzai, Y., Kim, H., Park, J.-Y., Wakabayashi, H. \& Oyaizu, H. (2000). Phylogenetic affiliation of the pseudomonads based on 16S rRNA sequence. Int J Syst Evol Microbiol 50, 1563-1589.

Chen, W. M., Laevens, S., Lee, T. M., Coenye, T., De Vos, P., Mergeay, M. \& Vandamme, P. (2001). Ralstonia taiwanensis sp. nov., isolated from root nodules of Mimosa species and sputum of a cystic fibrosis patient. Int J Syst Evol Microbiol 51, 1729-1735.

Coenye, T., Falsen, E., Vancanneyt, M., Hoste, B., Govan, J. R. W., Kersters, K. \& Vandamme, P. (1999). Classification of Alcaligenes faecalis-like isolates from the environment and human clinical samples as Ralstonia gilardii sp. nov. Int J Syst Bacteriol 49, 405-413.

Coenye, T., Goris, J., De Vos, P., Vandamme, P. \& LiPuma, J. J. (2003a). Classification of Ralstonia pickettii-like isolates from the environment and clinical samples as Ralstonia insidiosa sp. nov. Int J Syst Evol Microbiol 53, 1075-1080.

Coenye, T., Vandamme, P. \& LiPuma, J. (2003b). Ralstonia respiraculi sp. nov., isolated from the respiratory tract of cystic fibrosis patients. Int J Syst Evol Microbiol 53, 1339-1342.

De Baere, T., Steyaert, S., Wauters, G., De Vos, P., Goris, J., Coenye, T., Suyama, T., Verschraegen, G. \& Vaneechoutte, M. (2001). Classification of Ralstonia pickettii biovar 3/'thomasii' strains (Pickett 1994) and of new isolates related to nosocomial recurrent meningitis as Ralstonia mannitolytica sp. nov. Int J Syst Evol Microbiol 51, 547-558.

Dimech, W. J., Hellyar, A. G., Kotiw, M., Marcon, D., Ellis, S. \& Carson, M. (1993). Typing of strains from a single-source outbreak of Pseudomonas pickettii. J Clin Microbiol 31, 3001-3006.

Fass, R. J. \& Barnishan, J. (1976). Acute meningitis due to a Pseudomonas-like Group Va-1 bacillus. Ann Intern Med 84, 51-52.

Fujita, S., Yoshida, T. \& Matsubara, F. (1981). Pseudomonas pickettii bacteremia. J Clin Microbiol 13, 781-782.

Gardner, S. \& Shulman, S. T. (1984). A nosocomial common source outbreak caused by Pseudomonas pickettii. Pediatr Infect Dis 3, 420-422.

Goris, J., De Vos, P., Coenye, T. \& 7 other authors (2001). Classification of metal-resistant bacteria from industrial biotopes as Ralstonia campinensis sp. nov., Ralstonia metallidurans sp. nov. and Ralstonia basilensis Steinle et al. 1998 emend. Int J Syst Evol Microbiol 51, 1773-1782.

Hugh, R. \& Leifson, E. (1953). The taxonomic significance of fermentative versus oxidative metabolism of carbohydrates by various Gram-negative bacteria. J Bacteriol 66, 24-26.

Kahan, A., Philippon, A., Paul, G., Weber, S., Richards, C., Hazebroucq, G. \& Degeorges, M. (1983). Nosocomial infections by chlorhexidine solution contaminated with Pseudomonas pickettii (biovar Va-1). J Infect 7, 256-263.

Krieg, N. R. \& Holt, J. G. (1984). Bergey's Manual of Systematic Bacteriology, vol. 1. Baltimore: Williams \& Wilkins.

Lacey, S. \& Want, S. V. (1991). Pseudomonas pickettii in a paediatric oncology unit. J Hosp Infect 17, 45-51.

Laffineur, K., Janssens, M., Charlier, J., Avesani, V., Wauters, G. \& Delmee, M. (2002). Biochemical and susceptibility tests useful for identification of nonfermenting Gram-negative rods. J Clin Microbiol 40, 1085-1087.

Moissenet, D., Goujon, C. P., Garbarg-Chenon, A. \& Vu-Thien, H. (1999). CDC group IVc-2: a new Ralstonia species close to Ralstonia eutropha. J Clin Microbiol 37, 1777-1781.

Nemec, A., De Baere, T., Tjernberg, I., Vaneechoutte, M., van der Reijden, T. J. K. \& Dijkshoorn, L. (2001). Acinetobacter ursingii sp. nov. and Acinetobacter schindleri sp. nov., isolated from human clinical specimens. Int J Syst Evol Microbiol 51, 1891-1899.

Osterhout, G. J., Valentine, J. L. \& Dick, J. D. (1998). Phenotypic and genotypic characterization of clinical strains of CDC group IVc-2. J Clin Microbiol 36, 2618-2622.

Pickett, M. J. \& Greenwood, J. R. (1980). A study of the Va-1 group of pseudomonads and its relationship to Pseudomonas pickettii. J Gen Microbiol 120, 439-446.

Ralston, E., Palleroni, N. J. \& Doudoroff, M. (1973). Pseudomonas pickettii, a new species of clinical origin related to Pseudomonas solanacearum. Int J Syst Bacteriol 23, 15-19.

Raveh, D., Simhon, A., Gimmon, Z., Sacks, T. \& Shapiro, M. (1993). Infections caused by Pseudomonas pickettii in association with permanent indwelling intravenous devices: four cases and a review. Clin Infect Dis 17, 877-880.

Riley, P. S. \& Weaver, R. E. (1975). Recognition of Pseudomonas pickettii in the clinical laboratory: biochemical characterization of 62 strains. J Clin Microbiol 1, 61-64.

Roberts, L. A., Collignon, P. J., Cramp, V. B., Alexander, S., McFarlane, A. E., Graham, E., Fuller, A., Sinickas, V. \& Hellyar, A. (1990a). An Australia-wide epidemic of Pseudomonas pickettii bacteraemia due to contaminated 'sterile' water for injection. Med J Aust 152, 652-655.

Roberts, S. J., Eden-Green, S. J., Jones, P. \& Ambler, D. J. (1990b). Pseudomonas syzygii sp. nov., the cause of Sumatra disease of cloves. Syst Appl Microbiol 13, 34-43.

Sahin, N., Isik, K., Tamer, A. Ü. \& Goodfellow, M. (2000). Taxonomic position of 'Pseudomonas oxalaticus' strain Ox14 ${ }^{\mathrm{T}}\left(\mathrm{DSM} 1105^{\mathrm{T}}\right.$ ) (Khambata and Bhat, 1953) and its description in the genus Ralstonia as Ralstonia oxalatica comb. nov. Syst Appl Microbiol 23, 206-209.

Seal, S. E., Jackson, L. A., Young, J. P. W. \& Daniels, M. J. (1993). Differentiation of Pseudomonas solanacearum, Pseudomonas syzygii, Pseudomonas pickettii and the Blood Disease Bacterium by partial 16S rRNA sequencing: construction of oligonucleotide primers for sensitive detection by polymerase chain reaction. J Gen Microbiol 139, 1587-1594.

Steinle, P., Stucki, G., Stettler, R. \& Hanselmann, K. W. (1998). Aerobic mineralization of 2,6-dichlorophenol by Ralstonia sp. strain RK1. Appl Environ Microbiol 64, 2566-2571.

Taghavi, M., Hayward, C., Sly, L. I. \& Fegan, M. (1996). Analysis of the phylogenetic relationships of strains of Burkholderia solanacearum, Pseudomonas syzygii, and the blood disease bacterium of banana based on 16S rRNA gene sequences. Int J Syst Bacteriol 46, $10-15$.

Tans-Kersten, J., Huang, H. \& Allen, C. (2001). Ralstonia solanacearum needs motility for invasive virulence on tomato. J Bacteriol 183, 3597-3605.

Tatum, H. W., Ewing, W. H. \& Weaver, R. E. (1974). Miscellaneous Gram-negative bacteria. In Manual of Clinical Microbiology, 2nd edn, pp. 270-294. Edited by E. H. Lennette, E. H. Spaulding \& J. P. Truant. Washington, DC: American Society for Microbiology.

Vandamme, P., Goris, J., Coenye, T., Hoste, B., Janssens, D., Kersters, K., De Vos, P. \& Falsen, E. (1999). Assignment of Centers of Disease Control group IVc-2 to the genus Ralstonia as Ralstonia paucula sp. nov. Int J Syst Bacteriol 49, 663-669.

Vaneechoutte, M., Boerlin, P., Tichy, H.-V., Bannerman, E., Jäger, B. \& Bille, J. (1998). Comparison of PCR-based DNA fingerprinting techniques for the identification of Listeria species and their use for atypical Listeria isolates. Int J Syst Bacteriol 48, 127-139.

Vaneechoutte, M., Claeys, G., Steyaert, S., De Baere, T., Peleman, R. \& Verschraegen, G. (2000). Isolation of Moraxella 
canis from an ulcerated metastatic lymph node. J Clin Microbiol 38 3870-3871.

Vaneechoutte, M., De Baere, T., Wauters, G., Steyaert, S., Claeys, G., Vogelaers, D. \& Verschraegen, G. (2001). One case each of recurrent meningitis and hemoperitoneum infection with Ralstonia mannitolilytica. J Clin Microbiol 39, 4588-4590.

Verschraegen, G., Claeys, G., Meeus, G. \& Delanghe, M. (1985). Pseudomonas pickettii as a cause of pseudobacteremia. J Clin Microbiol 21, 278-279.

Wauters, G., Driessen, A., Ageron, E., Janssens, M. \& Grimont, P. A. D. (1996). Propionic acid-producing strains previously designated as Corynebacterium xerosis, C. minutissimum, C. striatum, and $\mathrm{CDC}$ group $\mathrm{I}_{2}$ and group $\mathrm{F}_{2}$ coryneforms belong to the species Corynebacterium amycolatum. Int J Syst Bacteriol 46, 653-657.

Wauters, G., Van Bosterhaut, B., Janssens, M. \& Verhaegen, J. (1998). Identification of Corynebacterium amycolatum and other nonlipophilic fermentative corynebacteria of human origin. J Clin Microbiol 36, 1430-1432.

Wauters, G., Claeys, G., Verschraegen, G., De Baere, T., Vandecruys, E., Van Simaey, L., De Ganck, C. \& Vaneechoutte, M.
(2001). Case of catheter sepsis with Ralstonia gilardii in a child with acute lymphoblastic leukemia. J Clin Microbiol 39, 4583-4584.

Woese, C. R., Gutell, R., Gupta, R. \& Noller, H. F. (1983). Detailed analysis of the higher-order structure of 16S-like ribosomal ribonucleic acids. Microbiol Rev 47, 621-669.

Yabuuchi, E., Kosako, Y., Oyaizu, H., Yano, I., Hotta, H., Hashimoto, Y., Ezaki, T. \& Arakawa, M. (1992). Proposal of Burkholderia gen. nov. and transfer of seven species of the genus Pseudomonas homology group II to the new genus, with the type species Burkholderia cepacia (Palleroni and Holmes 1981) comb. nov. Microbiol Immunol 36, 1251-1275.

Yabuuchi, E., Kosako, Y., Yano, I., Hotta, H. \& Nishiuchi, Y. (1995). Transfer of two Burkholderia and an Alcaligenes species to Ralstonia gen. nov.: proposal of Ralstonia pickettii (Ralston, Palleroni and Doudoroff 1973) comb. nov., Ralstonia solanacearum (Smith 1896) comb. nov. and Ralstonia eutropha (Davis 1969) comb. nov. Microbiol Immunol 39, 897-904.

Ziemke, F., Höfle, M. G., Lalucat, J. \& Rosselló-Mora, R. (1998). Reclassification of Shewanella putrefaciens Owen's genomic group II as Shewanella baltica sp. nov. Int J Syst Bacteriol 48, 179-186. 